\title{
Obituary of Professor Paul (Pavlos) Marinos
}

\author{
David G. Toll
}

Accepted: 21 October 2021 / Published online: 3 November 2021

(C) The Author(s), under exclusive licence to Springer Nature Switzerland AG 2021

It is with great sadness that we announce the passing of our dear friend and colleague, Professor Paul (Pavlos) Marinos on Sunday 10th October 2021. Paul was an Editor-in-Chief of Geotechnical and Geological Engineering since 2010. He was active in his editorial role until the day he died.

Paul was a leading figure in Engineering Geology and Rock Mechanics. He made great contributions to the field of rock mass characterisation, weak rock properties and behaviour (particularly in karstic terrain) with strong emphasis on applications to engineering design and construction. Paul was a leader of the profession as President of International Association for Engineering Geology and the Environment (IAEG), President of the Geological Society of Greece and of the Greek Tunnelling Society (a member of the International Tunnelling and Underground Space Association). He received many awards indicative of his great international standing, including:

- Honorary President of International Association for Engineering Geology and the Environment (IAEG) (2020)

- Knight of the order of "Palmes Académiques" from the French Republic (2014)

D. G. Toll ( $ه)$

Durham, UK

e-mail: d.g.toll@durham.ac.uk
- Richard H. Jahns Distinguished Lecturer, Environmental and Engineering Geology Division and the Association of Engineering Geologists, Geological Society of America (2010)

- Rock Mechanics Annual Lecture, Madrid (2006)

- 33rd Cross Canada Lecture Tour Lecturer of the Canadian Geotechnical Society (2005)

- 6th Glossop Lecture and Medal of the Geological Society of London (2002)

- 19th Rocha Lecture, Lisbon (2002)

- Hans Cloos medal, IAEG (2000)

- André Dumont medal of the Geological Society of Belgium (1999)

While we all can recognise the wonderful professional achievements of Paul Marinos, I am fortunate to be able to remember a long history of personal friendship. I first met Paul when I joined Durham University in 1988. Paul was a close friend of my colleague and mentor at Durham University, Professor Peter Attewell. Paul and Peter had forged a strong collaboration in Engineering Geology and we held a joint ERASMUS student exchange programme linking Durham University and National Technical University of Athens (NTUA). A large number of Greek students joined our MSc Course in Engineering Geology at Durham and Paul was frequently involved in co-supervisions and facilitating fieldwork in Greece. Like all great Engineering Geologists, Paul loved fieldwork, and I remember with particular 
fondness, trips to Greece to visit Assomata and Sfikia dams with Paul in the 1990s.

While reflecting upon the illustrious career of our Editor-in-Chief, we can also look back over the development of the journal. Geotechnical and Geological Engineering was launched with its current title 30 years ago in 1991, having started its life as the International Journal of Mining Engineering in 1983, edited by Ian Farmer. Initially published by Chapman and Hall, in London, it was taken over by Kluwer Academic in the Netherlands in 1997, which merged with Springer in 2004 who, with further mergers, became the current publisher Springer Nature in 2015.

It is a strange quirk of fate that $\mathrm{I}$, as the Editor responsible for the launch of Geotechnical and Geological Engineering in 1991, find myself now acting as Interim Editor-in-Chief in our $30^{\text {th }}$ year! Jim Hanson, our Co-Editor-in-Chief is taking a period of medical leave. We wish Jim well in his recovery and look forward to him resuming his role in 2022.

I edited the journal from its inception with the current title in 1991, with support from Kunsoo Kim from 1997, until 2005 when I handed over responsibility for the journal to Braja Das. Subsequently, Tuncer Edil took over the reins before passing them on to the present team of Jim Hanson and Paul Marinos. Beyond the editorial contributions, the success of the journal is in large part due to our publishing editor, Petra van Steenbergen, who has overseen the journal since its Kluwer Academic days.

So, although this is a time of sadness, we can also celebrate the great achievements of Geotechnical and Geological Engineering in achieving 30 years of publishing excellent articles that have promoted research and practice in our field. We thank our esteemed colleague, Paul Marinos, for contributing to our history. Rest in Peace.

David G. Toll

Interim Editor-in-Chief

Publisher's Note Springer Nature remains neutral with regard to jurisdictional claims in published maps and institutional affiliations. 